\title{
Ibn Khaldun
}

\author{
Syed Farid Alatas \\ New Delhi: Oxford University Press, 2013. 160 pages.
}

Syed Farid Alatas' Ibn Khaldun is a welcome addition to an emerging Khaldunian sociology. It represents one of the few socio-historical studies of his thought that pays attention to this North African thinker's historical milieu and life. Regarded by many scholars as a precursor of sociology, Ibn Khaldun (1332-1406) is also known for his contributions to the philosophy of history. His pioneering work, Kitāb al-'Ibar, is more than just a historical account of the Arabs and Berbers. Popularly known as the Universal History, it contains the important Muqaddimah (Prolegomenon) that details his "science of human society" ( 'ilm al-ijtima ' al-insāni $)$ or "science of human social organization" ( 'ilm al- 'umrān al-basharì).

This six-chapter book opens with "Ibn Khaldun's Autobiography and His Character," which outlines his life and presents other biographies that provide the socio-intellectual context of his thought. The second chapter, "Ibn Khaldun's Science of Society," focuses on his founding of the science of human society and is followed by "Ibn Khaldun on Education and Knowledge," which examines his modern educationist views of pedagogy and knowledge in terms of its social, political, and economic aspects. Alatas shows that Ibn Khaldun's perspective on education, as seen through the various lenses of history and sociology, was refreshingly different from the then dominant perspectives of philosophers, theologians, moralists, and jurists.

The ensuing chapter, "The Reception of Ibn Khaldun," situates him in the evolution of Islamic thought and contemporary social sciences, whereas the two final chapters, "The Significance of Ibn Khaldun for the Modern Social Sciences" and "Further Reading and Works Cited," encapsulate Alatas' suggestions for developing a Khaldunian sociology and include a list of further readings, alongside discussions on works ranging from Ibn Khaldun's biography to critiques of his methodology.

In the introductory chapter, which provides the context for the formation of Ibn Khaldun's thought, readers are better able to appreciate his empirically oriented scholarship. Embedded in the politically fragmented Maghrebian society, his political career as a judge and government official required him to shift his political loyalties consistently. This played a determining role in developing his ideas on how states rise and decline. Alatas highlights Ibn Khaldun's political involvement as instrumental in his systematic uncovering of the flaws in existing historical works. Ibn Khaldun himself identifies seven causal 
errors of history: partisanship with opinions and schools, reliance on transmitters, lack of awareness of an event's purpose, unfounded assumptions related to the truth of an event, ignorance of the conformity between conditions and actual events, ingratiation, and ignorance of the nature of societal conditions. All of these reflect the need for a new science of human society, one that would be in the service of history. Knowledge of the nature of a given society, he states, is key to critical historical writing. Thus a theoretically speculative history is one that is concerned with history's inner (bätin) meaning - which Ibn Khaldun refers to as the science of human society - and examines the origins and causes of events reported at history's surface ( $z \bar{a} h i r)$ level.

More importantly, according to Alatas, the distinguishing trait of Ibn Khaldun's science of human society is its normative nature. Compared to prescriptive past works that address such common topics as dynasties, politics, and government, this fourteenth-century scholar shows his originality of thought by examining the study of states and societies as they are, rather than as they should be. This new science, which he developed in his Muqadimmah, revolves around the various aspects that shape society and influence social organization, such as kingship, the modes of making a living or occupation, and the sciences and crafts. This approach was considered a new and independent science, one with its own subject of study (human organization or human society) and set of problems (explanation of societal conditions). Alatas notes that it is divided into three components: premises of the science of human society, the theory of the rise and decline of states, and methods.

Using rational demonstration (burhān) and embracing the necessity of human society as a premise, Ibn Khaldun's theory of the rise and decline of states examines the various causes of political change and social organization. It looks at the rise of new societies as a consequence of conflict and interaction between nomadic and sedentary societies, which are different in nature. For instance, he notes a greater degree of fortitude among the Bedouins than sedentary populations and argues that the latter's practice of enforcing the law by punishing offenders not only destroys its peoples' fortitude due to the consequent feeling of humiliation, but also increases society's dependence upon laws rather than the abilities of their inhabitants. In addition to the Bedouins' fortitude, Ibn Khaldun locates their high degree of 'așabiyah (social solidarity) at the center of his theory on the grounds that it is far more potent than any other form of solidarity. Since social groups with a stronger 'așabiyah are more durable, he asserted that a new state's formation depends upon it.

Nevertheless, Alatas notes further that Ibn Khaldun's conceptualization of this feeling is a type of social solidarity that emphasizes blood ties. Although 
clientship and alliance are two other types of relationship that can result in 'așabiyah, this latter blood-based relationship is the most powerful. Therefore, affiliation and clientship may become more dominant in those groups whose blood ties weaken and result in weaker forms of group feeling.

Perhaps the book's most significant contribution in the author's suggestion for a wider application of Ibn Khaldun's theoretical framework in the social sciences. Despite the shared traits that his new science has with modern sociology and social sciences, this North African scholar's ideas remain underutilized as a source of concepts in modern social science. Alatas claims that Ibn Khaldun's works are marginalized in terms of theoretical application and reconstruction into modern sociological theory. Even when his work is studied, it remains within the purview of western concepts and theories and limited to his proclaimed role as a forerunner of modern social science. As such, Alatas emphasizes the need for more methodological and theoretical work that empirically engages Ibn Khaldun's ideas in both historical and contemporary contexts. The author nevertheless cautions against using modern concepts to discuss Ibn Khaldun's ideas and attributing modern ideas to him.

Specifically, Alatas notes three areas for the further development of Ibn Khaldun's ideas: (1) integrating his thought into existing theoretical social science perspectives, (2) developing Khaldunian concepts, and (3) analyzing topics discussed by Ibn Khaldun. He identifies the importance of distinguishing between developing the Khaldunian approach and theory by using Ahmad Barakat's analysis of the Prophet's reported extermination of Madinah's Jewish Banu Qurayzah tribe in 5/627 (Muhammad and the Jews: A Re-examination: 1979). Applying Ibn Khaldun's rule of the critical acceptance of historical information as transmitted, alongside knowing the principles of politics and culture, Ahmad argues that the transmitted account cannot be accepted as accurate. Although Alatas shows the continued relevance of Ibn Khaldun's works by providing empirical illustrations of how his theory can be applied to both historical and contemporary contexts, these illustrations remain limited in their explanations of how Ibn Khaldun's conceptual analysis can be applied in today's world. Alatas' forthcoming Applying Ibn Khaldun: The Recovery of a Lost Tradition in Sociology (2014), may, however, address this weakness.

The book is a welcome publication, given that the existing literature on Ibn Khaldun is predominantly restricted to biographies, analysis of his works as a precursor of the social sciences, comparative studies with other westernoriented scholars, and broad surveys of his ideas specifically in the Muqaddimah (Enan 1953, Gellner 1981, Baali 1992, and Cheddadi 2006). Given the emphasis on Eurocentric concerns, an approach that causes European concepts 
and categories to dominate and leads to the marginalization of non-western thinkers and thought, this book is a timely contribution. Although Ibn Khaldun is seen as the first modern Muslim intellectual, his ideas have only had a minimal influence upon the development of Muslim thought for several centuries. Interestingly enough, it was the European thinkers of the nineteenth-century - a formative period for many modern social science disciplines - who first valued him as an original thinker. The author's decision to revisit Ibn Khaldun's scholarship in the final section of the book presents a fitting conclusion to a work that will potentially energize the emergence of a Khaldunian sociology. Ibn Khaldun is definitely required reading for anyone interested in Islamic thought and history, as well as in sociology.

Nurhidayahti Mohammad Miharja Doctoral Candidate, Sociology, School of Social and Political Science University of Edinburgh, Edinburgh, United Kingdom 